\title{
On the Consumption Concept of Contemporary College Students
}

Chunfu Yang ${ }^{1, \text { a }}$, Dongliang Yang ${ }^{2, \mathrm{~b}}$, Weihong $\mathrm{Min}^{3, \mathrm{c}^{*}}$ and Yunping Zhang ${ }^{4, \mathrm{~d}}$

${ }^{1}$ College of Animal Science and Technology, Jilin Agricultural University, Changchun 130118, China

${ }^{2}$ College of Information and Technology, Jilin Agricultural University, Changchun 130118, China

${ }^{3}$ College of Food Science and Engineering, Jilin Agricultural University, Changchun 130118, China

${ }^{4}$ Financial Department, Jilin Agricultural University, Changchun 130118, China

*The corresponding author: Weihong Min, Professor, female, born in August, 1971, interested in food science.

ayangchunfu197242@163.com, b610557217@qq.com, 65817713@qq.com, '798301739@qq.com

*The corresponding author

Keywords: College students; Consumption status; Consumption view; Formation cause; Countermeasure

\begin{abstract}
Contemporary college students are gradually becoming mature groups. As a special consumer group, their consumption behavior directly reflects their consumption concept and value orientation. Whether their consumption concept is scientific and reasonable has an important effect on whether they can form a scientific and noble outlook on life. With the increasing abundance of material wealth and spiritual wealth, there have been a lot of abnormal phenomena in college students' consumption, which has a negative impact. It is incumbent upon us to pay attention to the consumption of college students, to explore their causes, to guide them to establish a correct view of consumption and to promote the improvement of their ideological and moral qualities.
\end{abstract}

\section{Introduction}

Contemporary college students as a special group of social consumption, has some distinct consumption characteristics: No income, a single source of consumption, with strong consumer demand. The consumption status of college students reflects their living condition and value orientation to some extent. The shaping and cultivation of their consumption concept will have an important influence on their life. How to cultivate college students to establish a correct view of consumption, help them develop good habits of consumption, establish a positive, healthy and upward way of life. This is the new topic of Ideological and political work in Colleges and universities should be paid to more attention.

\section{Consumption Status of Contemporary College Students}

College students can not only meet the needs of their own learning and life, but also to meet the needs of entertainment. Through investigation and research, it is found that the consumption of contemporary college students is scientific and reasonable. However, due to some of their own factors and external factors, there are still some misunderstandings in the consumption of contemporary college students, which restricts the consumption of College students. Mainly in the following areas: 
Severe Psychological Comparisons, Excessive Pursuit Of Famous Brand. Many college students are not according to their own needs to consume, but to see others have, they have to get. Because of vanity, they eat and wear on the pursuit of brand. This blind comparison, excessive pursuit of the concept of brand consumption seriously restricts the contemporary college students to establish a correct and reasonable consumption concept. [1]

Irrational Consumption Structure. For their outstanding performance of material consumption approached, and the spiritual and cultural consumption is lagging behind. In the spiritual and cultural consumption level, we should pay attention to entertainment and consumption, and light intellectual consumption. [3]The material as to highlight their personality and realize self-value in the field of material life, more fun, comfortable lifestyle, neglected in the traditional virtue of thrift. [2]

Blind Consumption, Lack of Rational Thinking. The vast majority of college students' consumption is not rational thinking, often indiscriminate consumption. Some even have no money in the middle of the month, can only rely on borrowing to live, so the consumption in advance is very popular among college students. College students buy what they want, but they don't know if they really need it, or even spend nearly a month living on their own. Therefore, this consumption is not rational enough.

\section{Causes of Unhealthy Consumption Concept of College Students}

Social Environmental Impact. Consumption activities are always under certain social and economic conditions. As a social person, the consumption behavior and consumption concept of college students are inevitably affected by the social environment. Nowadays, the diversification of the concept of consumption has hindered the college students' consumption patterns, and the view of money is the most important one. Some film, television, newspapers and other mass media transmission of information is also full of luxury high consumption concept. [4]These make the lack of identification ability of college students is extremely easy to be affected, resulting in unhealthy consumption concept.

The Lack of School Consumption Concept Education. The phenomenon of bad consumption of contemporary college students has a great relationship with the lack of health education. At present, many universities only focus on the transmission of knowledge and skills training, attention to students' academic performance, and even the use of academic achievements to measure the pros and cons of students, but consumer education is almost missing. In addition, colleges and universities have not set up a glorious economy, a good atmosphere of waste shameful. [5]

Improper Family Consumption Education. The imperfection of family education is one of the important factors that lead to unhealthy consumption habits. Most parents don't pay attention to the concept of children's consumption concept. Some parents think that the child alone in the field to learn to spend more does not matter, as well as parents feel that when the child will be able to make money after the formation of a healthy consumer attitudes. More and more parents even noticed it, only verbally tell children "don't do", and they are wasteful, this is a failure of family education.

Individual Factors of College Students. The formation of College Students' consumption concept and the choice of consumption behavior to a large extent depend on the internal cause, which is influenced by their own consumption mentality. Contemporary college students are not yet fully mature, consumer psychology is not rational enough, did not form a correct outlook on life, world outlook and values. They are easy to be fooled by all kinds of vanity, blind consumption and consumption. [6]This leads to a change in the mentality of College Students' consumption. Although the contemporary college students are adults in physiology, they are still minors, their 
consumption psychology is not perfect, and even unhealthy. On the one hand, it is related to the lack of financial education in family education, on the other hand, due to the lack of a correct understanding of self, low level of self-control.

\section{Actively Guide College Students to Establish a Correct View of Consumption}

The internal factors and external factors, so that the contemporary college students' consumption concept to some extent, there are errors. In order to enable them to establish a correct view of consumption, we should take all kinds of measures to guide college students to establish a scientific and rational consumption concept.

Schools should Strengthen the Education of Students' Consumption Concept. College Students' consumption experience is mainly in the school, they gradually get rid of dependence on parents, whether living or learning the basic necessities of life consumption, development of consumption test, are beginning to follow their own will to choose the object of consumption. Therefore, the school to guide college students to establish a correct view of consumption. On the one hand, schools should set up financial management, investment and other courses, lectures and other forms, to create a healthy consumer habits in the students; On the other hand, schools should improve the sense of crisis of college students, encourage students to pursue the study of consumption, the money spent in the place. [7] In addition, the school also can take more part-time job, let the student through work will hone and develop practical ability.

Strengthen the Guidance and Education of College Students' Consumption Concept. The university campus is a small society, and the big society is inextricably linked, college students' unhealthy consumption patterns, consumption concept can always find the corresponding shadow in society. Therefore, we should give full play to the social impact of the school, and vigorously promote the "saving glory, waste shameful" concept and spirit, and eliminate waste on the tongue, resist wasteful and hedonism, promote the socialist civilization new fashion, let the positive energy society to guide college students' correct consumption. [8]

Parents should Pay Attention to the Development of children's Correct Consumption Concept. Family environment, parents' consumption patterns and consumption concept have irreplaceable effects on to form their outlook on consumption. Facts tell us: a good family environment for college students to create a correct view of the role of consumption is subtle. [9]First, parents should set a good example for their children, parents should develop rational consumption, saving the consumption habits in daily life, let the children understand the truth of saving; The second is to cultivate awareness of financial management. We should learn from foreign advanced educational concepts, deliberately cultivate children's financial management skills, develop a sense of rational consumption. [10]

Improve the Ideological Quality of College Students, Establish a Correct View of Consumption. School, society and family are external factors, the improvement of College Students' ideological quality is the internal cause. A pressing matter of the moment is to help students establish a correct outlook on life and values, let students understand what is the normal consumption, what is blind consumption, develop their own right, independent consciousness, rational financial management, adhere to the principle of rational consumption, develop good spending habits. 


\section{Summary}

In conclusion, as college students should establish a rational and civilized consumption concept, the formation of health, quality of consumption patterns, create a positive, comply with the requirements of the consumer culture in the society, the harmonious development of the society.

\section{References}

[1] C.W.Song: Guidance and Exploration of College Students to Establish Correct Consumption Concept [J]. Science and Technology Innovation Herald.2011(12): 10-11(In Chinese)

[2] Q.Y.He:Ideological Education Should Pay Attention to the Guidance of College Students' Consumption Behavior [J]. Ideological Education Research.2012(3) : 22-24.(In Chinese)

[3] Q.Wu:A Survey of College Students' Consumption [J]. Journal of Shanxi finance and economics university.2013(3) : 5-8. (In Chinese)

[4] G.Q.Fu: Consumer Behavior [M].Beijing: Higher Education Press, 2010. (In Chinese)

[5] P.Gu: Research on the Problems and Countermeasures of Contemporary College students' Consumption Concept [J].Cang Sang, 2008(2) : 124-125. (In Chinese)

[6] S.S.Wu: Reflections on the Consumption Concept of Contemporary College Students in the Consumer Society [J]. Journal of Science (First Half), 2011(5) : 44-45. (In Chinese)

[7] H.P.Zhang: Problems and Solutions of Modern College Students' Consumption Concept [J] Labor and social security (Theory), 2011(1) : 86-88. (In Chinese)

[8] H.Wang: Investigation and Analysis of College Students' Consumption Concept [J]. Marketing Online, 2010(7) : 77-78. (In Chinese)

[9] G.J.Ni: The Concept of Dialectical Thinking Chinese Traditional Consumption from the Perspective of Ecological Environment [D].Dalian: Dalian Maritime University 2012. (In Chinese)

[10]D.D.Fu: Research on the Guidance of Contemporary College Students' Green Consumption Concept [D], Qiqihar: Qiqihar University, 2012.(In Chinese) 